Ssciendo Studia Anglica Posnaniensia 54 (2019): 113-132

doi: 10.2478/stap-2019-0006

\title{
THE MIDDLE ENGLISH CREOLIZATION HYPOTHESIS: PERSISTENCE, IMPLICATIONS, AND LANGUAGE IDEOLOGY
}

\author{
DAVID O’NEIL ${ }^{1}$
}

\begin{abstract}
Bailey and Maroldt (1977) and Domingue (1977) were the first to argue that language contact during the Middle Ages between Old English and both Old Norse and Norman French resulted in linguistic creolization. This theory, known as the Middle English creolization hypothesis, implies that Middle English, and perhaps Modern English as well, should be classified as a creole. Though frequently discredited on historic, linguistic, and terminological grounds, the creolization hypothesis has attracted interest for longer than might be expected. This paper argues that the persistence of the hypothesis may be ideologically motivated. The first section examines connotations of the term "creole" and applies these connotations to an analysis of the initial presentations of the creolization hypothesis. The second and third section of the paper review and analyze the forty-year history of the debate, focusing separately on arguments for creolization (and koinezation) between Anglo-Norman French and Old Norse, respectively. The fourth and final section examines challenges presented by the concept of creole exceptionalism to common attitudes about language equality and the theory of Universal Grammar. It is argued that these issues attract greater interest when contextualized within a discussion of a "major" world language such as English than when creolization is understood as an atypical process restricted to "peripheral" languages such as Haitian Creole. This paper also references relevant political issues such as the current controversy among medievalists about the field's historic lack of inclusivity.
\end{abstract}

Keywords: Middle English; creolization hypothesis; creole; koine; history of English linguistics; language ideology.

\section{Introduction}

The term "creole" has been used by linguists and other language scholars for a long time, yet consistent definition remains elusive. According to Görlach, specialists have frequently redefined the term "to make it satisfy the specific

1 David O'Neil, University of Southern Indiana, 8600 University Boulevard, 47712 Evansville, IN, United States, david.oneil@usi.edu 
needs of their arguments" (1986: 330), and McWhorter argues that "there remains a gaping lack of consensus in the subfield as to what a creole even is" (2005: 37). As might be expected, confusion is even more likely among nonspecialists. Watts recounts a debate from an internet-based language forum in which practically everyone had his or her own definition. Some participants believed that creoles were by definition the result of European colonialism (for some, only French colonialism), and others argued that a creole was just a simplified language, a "bastard" that resulted from extended language contact regardless of geographical, cultural, or social context. Only one commenter offered the classical definition that a creole was "a pidgin language which has become a mother tongue" (2011: 86-87). Clearly, a definition for the term has not been easy to agree on. Even among specialists, determining which languages should be classified as creoles has often entailed significant and lasting controversy. One example of such controversy is the forty-year debate over the Middle English creolization hypothesis.

The presence of the Middle English creolization hypothesis in the scholarly literature has been durable, yet paradoxically the hypothesis itself is not popular among language scholars. From its first articulation in the late seventies, it has faced strong and repeated criticism on terminological, historic, and linguistic grounds - as seen, for example, in responses by Poussa (1982), Görlach (1986), Thomason \& Kaufman (1988), Dalton-Puffer (1995), Allen (1997), Danchev (1997), Hogg (1997), McWhorter (2005), Watts (2011), and Trotter (2017). The fact that interest has continued in the face of such opposition suggests there is more involved than the linguistic classification of a single language. In this paper, I argue that the mere idea of classifying English as a creole has ideological resonance that provokes our conception of English as a language, as well as our general understanding of language and language change. Most obviously, the hypothesis entails classifying a "major" European language alongside "minor" Caribbean languages such as Haitian Creole and Jamaican Patois, and for many scholars this association may be either intriguing or uncomfortable. Less obviously, creolization presents challenges to general assumptions about linguistic inheritance and linguistic complexity - challenges which are harder to ignore when contextualized within the discussion of a language such as English, raising the stakes for the debate in ways that might not be expected. In Section 2 I discuss why creolization debates are so often ideologically charged, focusing on claims made by the first proponents of the hypothesis. In Sections 3 and 4 I present overviews of linguistic and historical arguments surrounding the hypothesis, noting ramifications of the discussion that extend beyond the narrow limits of the field. Finally, in Section 5 I discuss ideological implications of creolization and creole exceptionalism as they relate to our conception of the general human language capacity. 


\section{Creolization and language ideology}

Given its connotative associations, conversations surrounding creoles and the process of creolization are often ideologically charged. DeGraff (2003), for example, argues that the term has been incurably tainted by its origins in nineteenth-century colonialism - and he has a point. Consider the frank racism in what passed as a scholarly discussion of creoles in 1889:

\footnotetext{
Creole languages result from the adaptation of a language, especially some IndoEuropean language, to the (so to speak) phonetic and grammatical genius of a race that is linguistically inferior. The resulting language is composite, truly mixed in its vocabulary, but its grammar remains essentially Indo-European, albeit extremely simplified. (after DeGraff 2003: 393)
}

Frank comments such as this one about linguistic inferiority and the "grammatical genius of a race" are, for the most part, long gone from the field, but this disciplinary history has cast a long shadow over modern-day conversations about creolization. Some scholars are understandably hesitant to ascribe special characteristics to languages spoken by colonized peoples, who have a long history of being categorized as "other." This history may partly explain why discussions of creoles and creole theory may attract greater interest than might be expected from their otherwise narrow academic content, especially when the debate is over a language such as English that has tended to fill the lexifier role in accounts of creolization. Merely to contemplate the idea of English as a creole has the power to challenge stereotypes, subvert the problematic early history of creole studies, and foreground questions that might otherwise have been neglected.

The hypothesis that Middle English was a creole originated in the work of Bailey and Maroldt (1977) and Domingue (1977), who independently argued that the linguistic change evident in the transition from Old to Middle English should be attributed to language contact and creolization. In the first appearance of the hypothesis, Bailey and Maroldt argued for two accounts of this process, which were based on grammatical influence and the frequency of loan words in English. The first account was that Middle English was a creole that resulted from the mixing of Old English and Norman French after the mid-eleventhcentury invasion of England under William the Conqueror. In short, French acted as superstrate, or lexifier, to an Old English substrate, and the language contact continued as long as speakers of Norman French filled positions of power in England (until about the thirteenth or fourteenth century). Bailey and Maroldt also claimed that, even prior to the creolization of Middle English, Old English had already undergone creolization during its ninth- and tenth-century contact with Old Norse. Together, these claims imply English was creolizing for around 500 years, which is a somewhat surprising assertion considering the 
conventional view that creolization is a rapid process that takes place within a few generations.

But Bailey and Maroldt rely on a broader definition of creoles. As they put it, creoles are "the result of mixing which is substantial enough to result in a new system, a system that is separate from its antecedent parent systems" (1977: 21). This definition is criticized by Görlach (1986) on the grounds that it would allow almost any language to be classified as a creole, but it's doubtful Bailey and Maroldt would mind this criticism given their claim that all languages should be represented, "like humans," as having two parents rather than one (1977: 22). With this claim, the authors reject the common view, represented in standard dendrograms, that languages descend from a single ancestor. They explicitly describe creolization not as a special linguistic process, but as a commonplace mechanism by which most if not all languages change over time. More than just our conception of English, Bailey and Maroldt were challenging our understanding of how, when, and where creolization occurs as a general process, and the current social, cultural, and political status of English made Middle English an ideal battleground for arguing that creoles are non-exceptional languages. Thus, even in its earliest expression, the creolization hypothesis was accompanied by a frankly ulterior motive: the desire to show creolization as a common, or even universal process of language change that all languages are subject to. In this work, the term "creole" seems to have been adopted, not for classificatory precision, but rather to highjack its rhetorical force.

Domingue independently proposed a creolization hypothesis the same year as Bailey and Maroldt, arguing that Middle English was not a "modernization" of Old English, but a "linguistic innovation" that resulted from contact with several languages (1977: 89). As support, she points to the very high frequency of French words in the Middle English lexicon and also to the smaller number of words of Scandinavian origin, which nevertheless account for a significant contribution to the lexical core, where loan words are less likely to be found (e.g., they, them, their, are, till, though, etc.). Domingue also finds evidence for creolization in Middle English's impoverished inflectional system, which she argues could have resulted either from the "convergence of several systems" or a "general trend toward simplification following universal rules" (1977: 92-93). In either case, she explains that contact with French and Old Norse drove the shift in English language syntax from relatively synthetic (Old English) to analytic (Middle English).

There are a couple of key differences between Domingue's and Bailey and Maroldt's understanding of creoles. One difference is that Domingue takes the orthodox position that a creole must develop from a pidgin (though no such pidgin exists in the historical record in the case of English). A more important difference, however, is Domingue's reluctance to make any definitive claims. At 
the outset, she goes no further than to state that Middle English is "very much alike a creole" (1977: 89) [emphasis mine], but she concludes with a serious consideration of the implications entailed by either strong position in the debate. On one hand, denying Middle English creole status could "be very helpful if we want to define the term creole more narrowly than we have done up to now" (1977: 97). On the other hand, if the claim of creolization is accepted for Middle English, then the historical processes of pidginization and creolization may be more widespread than usually considered. Thus, the designation of Middle English as a creole could impact our understanding of historical processes of how language families are constituted:

\begin{abstract}
It can then be argued that pidginization and subsequent creolization may be much more common than usually held. They may be widely spread processes in the history of languages... Proto-Germanic could be considered a creole language, as could Proto-Armenian and Proto-Albanian. Processes of pidginization and creolization can explain better than borrowing or areal influence the rationale behind the wave model for a classification of Indo-European. It might also well be that genetic classifications based on lexico-phonological correspondences are not only too rigid, but misleading, hiding facts of pidginization/creolization, because they do not take syntactic features into consideration. Such speculations strip pidgins and creoles of their status of 'special' languages and regard them as normal, though not necessary, steps in the formation of languages. (1977: 97)
\end{abstract}

In this discussion, Domingue speculates about the broader implications of the creolization debate, which are argued to extend well beyond English itself. Like Bailey and Maroldt, she sees the debate as a battlefield for larger issues in the field of historical linguistics. If English can be classified as a creole, she suggests, then maybe creoles are not exceptional.

Unlike Bailey and Maroldt, Domingue hesitates to defend the strongest form of the hypothesis, but she also places the burden of proof on those who would deny Middle English the status of creole. Is there "a specifically creole syntax which ME does not possess?" she asks (1977: 97). In the end, Domingue remains agnostic and suggests reserving the term "creole" for those languages in the West Indies and Indian Ocean whose speakers use the term for themselves. As an alternative, she proposes the term "hybrid" for languages that exhibit significant mixing - a solution that may avoid some of the terminological problems in creole theory, though at the cost of ignoring the question of whether pidginization and creolization really are distinct processes that explain the origins of certain languages. After all, if the term "creole" is divorced from the classical definition of "nativized pidgin", then not only does the term lose meaning, but an important concept may be lost. Markey offers a pointed observation about such attempts to redefine the term: "To label creóles 'contact languages' is vacuous: all languages are contact languages. To call all languages creóles is equally fatuous..." (1982: 170). Of the 
initial authors of the creolization hypothesis, Domingue is guilty of the first extreme (simplifying the term "creole" to "contact language"), and Bailey and Maroldt are guilty of the second (labeling all languages as creoles).

While Domingue hoped to circumvent the rhetorical challenges of the term "creole" by proposing a new term, for Bailey and Maroldt these challenges are rather the point. They openly object to standard views of linguistic inheritance and frankly contend that the standard tree model of linguistic ancestry should be rewritten to show lineage from multiple parents. To say the least, such a drastic revision of how language families operate would disrupt theories based on the standard model. Whether explicitly or implicitly, linguists tend to think of creoles and non-creoles as being derived from two completely distinct models of parentage. Bailey and Maroldt reject this distinction, but DeGraff (2003) makes an even more passionate case for the insidiousness of views that interpret creolization as an atypical process of linguistic inheritance. Since creoles and pidgins are segregated into their own "genetic" group marked by a lack of grammatical structure, he sees creole theory as a continuation of nineteenthcentury colonialist attitudes toward "inferior" races:

\footnotetext{
$[\mathrm{P}]$ idginization is an all-powerful structural simplification process that is claimed to, among other things, obliterate virtually all morphology and to lead to a preCreole early contact language - a 'macaronic' jargon or 'early pidgin' — whose extraordinary lack of structure makes it unlike any full-fledged human language and more like some protolanguage that may have been spoken by our (pre)-hominid ancestors. (2003: 398)
}

The main force of DeGraff's argument is that creole exceptionalism encodes historical prejudices, masking imperialist attitudes from a century ago under a veneer of technical argumentation. This point may be pushed even further. If pidgins are argued to have no direct ancestors in their genealogy, then both pidgins and creoles would have no place in a linguistic model that presents languages as related by common descent, casting creoles in an extreme position of genetic alterity.

So what happens if English, a language deeply associated with what Milroy calls the "ideology of the standard language" (2001a: 530), should be determined to be a creole? As I have argued, it may be that the creolization hypothesis for Middle English has been persistent in scholarly debate precisely because of its rhetorical power to provoke such challenges. English is a "major" member of the Indo-European language family, and its place on the world stage is currently so dominant that it has commonly been described as imperialistic (for linguistic imperialism, see Phillipson 1992; for the current role of English in international publishing, see O'Neil 2018). For this reason, issues regarding the classification of English are harder for the scholarly community to ignore than issues regarding 
"minor" colonial languages. This would be true even if the theoretical challenges for English were no different than they were for languages that are considered creoles uncontroversially. Even in its earliest framing, therefore, the creolization hypothesis was presented within an explicit ideological context. Bailey and Maroldt, in particular, were making a cross-linguistic, universal claim about linguistic inheritance. I argue that they picked English as the battleground in order to make other scholars pay attention.

No doubt, the strategy worked, but neither Bailey and Maroldt nor Domingue find much support in the subsequent literature, especially with regard to the French side of the hypothesis. In fact, Plag criticizes a fellow scholar for wasting time bothering to refute the hypothesis, insisting that it "has long been dismissed as thoroughly inadequate" (1998: 393). But I disagree that the hypothesis is unworthy of our attention. Despite its weak and perhaps intentionally iconoclastic presentation in some of the literature, the response has spurred interesting and productive work on the development of Middle English. Furthermore, it is sensible for scholars to be cautious when addressing a question with ideological ramifications. As a parallel case, Markey points out that the most strident opposition to defining Afrikaans as a creole has been associated with eurocentrism and white supremacy (in this context, creolization was described as "linguistic miscegenation," 1982: 170). The contact situation for English in the Middle Ages is not the same as colonial South Africa, but careful review of the evidence is merited when there may be even the faintest suspicion of problematic motives. And medievalists have reason to be especially sensitive right now. The field is currently embroiled in crisis about its lack of inclusivity, as illustrated by recent headlines from The New York Times and The Washington Post (just two of many examples). The headlines read, respectively, "Medieval Scholars Joust with White Nationalists. And One Another" (2019, May 5) and "It's All White People: Allegations of White Supremacy are Tearing Apart a Prestigious Medieval Studies Group" (2019, September 15). The first article addresses the general controversies currently shaking up the field; the second discusses a particular controversy centering on the connotative resonance of the term "Anglo-Saxon," which some critics argue should be discarded on the grounds that it has become a "code for whiteness". Again, the fact that "creole" has related ideological connotations (in a sense, nearly the converse connotations) helps explain the surprising degree of interest in the Middle English creolization hypothesis.

\section{Anglo-Norman French}

The strongest linguistic evidence against Middle English creolization is found in the arguments related to Anglo-Norman French (as opposed to Old Norse). One of the earliest critics, Poussa objects to the hypothesis's overreliance on evidence 
of lexical borrowing, maintaining that even large influxes of loanwords and translation calques are no proof of creolization in the usual sense unless there is also "evidence of more fundamental systemic change" (1982: 70). McWhorter makes much the same point, adding that even morphological borrowing is not conclusive (2005: 267). Obviously, the lack of a common set of criteria can make these arguments difficult to evaluate. Dalton-Puffer insists that the presence of similar features among languages in a contact situation is not enough for reliable classification "unless, of course, we are not too worried about being imprecise in our terminology" (1995: 48). In this, she shares Domingue's concern for establishing stricter definitions in creole studies. If all languages that result from contact are considered creoles, then perhaps the term is too diluted to serve any purpose outside its rhetorical function.

To illustrate the importance of caution in these arguments, Dalton-Puffer's employs a compelling argumentum ad absurdum, in which she shows that Middle English exhibited many similarities to dying languages. Examples of these features are the loss of traditional personal names, the reduction of productivity in word formation rules, and massive one-directional lexical borrowing. To be more specific on this last point, English absorbed massive amounts of Romance vocabulary from Norman French, while Norman French borrowed almost no words from English. In many of these cases, English did not lack the word for a particular concept, but gave up pre-existing English terminology in favor of Romance alternatives, such as in the case of merci and compassioun for the Old English mildheortnesse (1995: 43). Again, DaltonPuffer marshals this evidence in support of a conclusion that is demonstrably false (i.e., that Middle English was a dying language). The point is that historical conclusions based on speculative or circumstantial evidence are likely to be at odds with what actually occurred.

In addition to making this argumentum ad absurdum, Dalton-Puffer identifies specific problems with the view that Middle English resulted from creolization with French. For one, while a significant percentage of vocabulary in Middle English comes from French (as many as 50 percent of the distinct lexical entries represented in Chaucer), these borrowings were not used with nearly the same regularity as words of Old English origin. The actual number of French tokens in Middle English texts is quite small (in Chaucer, as low as 7 percent), because these tokens did not come from the lexical core. In other words, there are many lexemes in Chaucer borrowed from French, but these lexemes are infrequently used. As Dalton-Puffer argues, since the majority of Middle English vocabulary came from Old English, it makes little sense to consider Norman French a superstrate language and lexifier.

Besides changes in its lexicon, another important argument for creolization in English is the "sudden" impoverishment of inflectional morphology. However, 
Allen presents systematic manuscript evidence that the process of paradigmatic leveling appears to have preceded language contact with French or even Old Norse (although the contact in the latter case may have accelerated the process): "[T] he appearance of very rapid change in EME is to a large extent illusory, as the conservative practices of OE scribes often masked substantial changes which had already taken place before the Norman invasion" (1997: 64-65). Specifically, Allen demonstrates that syncretism in the nominal system was already well advanced during the Old English period and that the inflectional loss in northern Middle English was catalyzed by phonological changes rather than language contact. Moreover, similar changes in southern dialects in the eleventh century (such as loss of final 'n' and vowel reduction) could have led to the increasing use of the uninflected determiner since phonological distinctions became difficult or even impossible to perceive. At the same time, nominative-accusative distinctions became particularly weak (though authorial understanding of the basic inflectional system remains clear in many manuscripts, suggesting that syncretism was not the result of new speakers being confused about morphological categories). All these points find support in Hogg (1997), whose only refinement of Allen's position is to note that she underestimates the extent of pre-contact category loss, which strengthens her main point that inflectional loss in Middle English should not be taken as support for creolization.

The claim that morphosyntactic changes were occurring in English even before the Norman invasion is supported by evidence outside the creolization debate. In recent years, there has been growing interest in syntactic change as an explanation for the metrical evolution of the medieval English alliterative tradition (for example, in Hartman 2016; O'Neil 2017; Russom 2017). The argument can be summarized as follows: Parallel with the case syncretism discussed above, functors (words from closed-class, functional parts of speech such as pronouns and prepositions) increased in frequency to compensate for the meaning that had been expressed in the inflectional endings. Functors are composed of unstressed syllables, so this increase influenced the distribution of stressed and unstressed syllables in the alliterative line. Metrical analysis has shown that these changes were already evident during the Old English period. Hartman (2016) and Russom (2017) analyze the role of functors in the late Old English poem The Battle of Maldon, and O'Neil (2020, forthcoming) argues that syntactic change was appearing even earlier, showing a trend across six Old English poems leading up to the Middle English Brut. These data show that the oldest English alliterative poem, Cædmon's Hymn, contained an average of about one functor per two half-lines; mid-Old English poems like Beowulf and Andreas contained an average of about one functor per half-line; Maldon contained an average of about one-and-a-half functors per half-line; finally, the early Middle English Brut contained about two functors per half-line. Applied to the 
creolization debate, this evidence supports a model of gradual syntactic change rather than rapid creolization.

In addition to these linguistic arguments, the creolization hypothesis has also been disputed by means of historical reconstructions of the contact situation. Pidgins and creoles are not generally thought of as the product of literary contact, but of interpersonal communication in specific social situations. Yet our Middle English texts are not, as Dalton-Puffer points out, "classified as 'speech-based' let alone 'spoken"' (1995: 38). Instead, we need to consider the extent of interpersonal contact between speakers, and it seems likely that the contact between speakers of English and Norman French, due to the great social distance, would not have been the sort of contact that leads to the creation of a pidgin. This view is taken by McWhorter (2005) and Thomason and Kaufman (1988), who argue that there was too little contact between the French-speaking Norman invaders and the native English speakers to have had a significant effect on the grammatical characteristics of Middle English. To illustrate the point, Watts (2011) imagines a few language contact scenarios that would have been likely in post-invasion England. In one, an English-speaking peasant is called to testify before a French-speaking magistrate. This is a poor context for language contact because the peasant would not be expected to learn French for such a rare occurrence, while the French-speaking magistrate might simply have hired an interpreter. In a second scenario, an Englishspeaking clerk discusses financial accounts with a French-speaking lord. This is a poor context because the social distance between them would have put the onus of language learning on the clerk. Communication in French (even if poor French) seems more likely in this case than the mutual adoption of a pidgin. A counterargument could be made that extended contact between English and French speakers even in a small number of contexts (such as trade or legal matters) could have been enough to induce the creation of a pidgin. However, even if such a pidgin were to exist, only very small numbers of the English-speaking population would have had cause to use it. It seems improbable that the speech of such a group, the members of which obviously would not have spoken with other English speakers in the pidgin, could explain the radical transformation of the English language in the Middle English period.

Ingham (2014) provides an explanation for the widescale transfer of French vocabulary into Middle English that is much more compelling than the creolization hypothesis. Countering claims that French was a language of instruction during the middle of the Middle English period, he provides evidence that English speakers from the educated class became bilingual in Anglo-Norman French during middle childhood before they began formal language instruction in Latin (which they learned via French). Bilingualism, rather than contact between speakers of different languages, would thus have provided the basis for French influence on English: 


\begin{abstract}
Now French language influence on English is known to have been at its zenith between 1250 and 1350 (Dekeyser 1986), by which time monolingual French speakers were scarcely to be found, but bilingual speakers were the norm amongst the educated classes, so this was a period when French could indeed influence English via bilingual competence. Hence the known linguistic facts as regards French loans in English, and the acquisitional milieu we have argued for here, are in diachronic alignment. It is far less plausible to suppose that French could have influenced English so strongly, had it been merely an instructed foreign language, a status which it had in the 16th century (Kibbee 1991), when French loanword frequency had already sharply declined. (2014: 444)
\end{abstract}

At this period, French speakers in England would have been overwhelmingly bilingual, and it makes little sense to imagine a novel contact language arising between monolingual and bilingual speakers of English. Accordingly, the hypothesis that Middle English is a creole of French and Old English is rather weak on both linguistic and historical grounds.

\title{
4. Old Norse
}

As compared to contact between English and French, the technical case for creolization with Old Norse has some strengths. First, the historical setting was much more conducive to sustained contact between Old English and Old Norse since Danish and English farmers would have interacted on a regular basis for two centuries in the area of northern England known as the Danelaw. Notably, the northern dialects of Middle English from these areas show more advanced signs of morphological leveling (discussed above) than elsewhere in England, and inflectional loss is an essential part of any compelling argument for creolization. If we return to Watts and his imagined scenarios for linguistic contact, we can see that speakers in this area would be more likely to have interacted in a setting that might necessitate a common language. Although the image may be somewhat playful, Watts envisions an English and Scandinavian farmer sharing a jug of alcohol and chatting amicably after a day at the cattle market. In such scenarios, the contact would have been strictly oral rather than literary, and Dalton-Puffer argues that it is unlikely there was "any contact between written forms of Scandinavian and English" (1995: 48). In short, communication between English and Danish subjects of the Danelaw was likely to have been overwhelmingly interpersonal - a good context for creolization.

For these reasons, an early creolization process in the north (which also finds support in Poussa 1982) is much more plausible than a later process based on several centuries of English commoners interacting with Norman aristocrats. However, plausibility is hardly a decisive consideration. According to Thomason and Kaufman, the "pervasive" Norse influence was shallow and unevenly distributed in all areas of the language aside from the lexicon, and the similarities 
between Norse and English precluded the possibility of the former making a significant mark on the typology of the latter (1988: 302-303). On the other hand, McWhorter claims that an "incomplete acquisition of English" among Scandinavians learning English as a second language could explain the early inflectional loss characteristic of northern dialects (2005: 305), and similarities between the languages would not eliminate this effect. This argument is presented with even greater clarity and force in McWhorter (2008).

If this is indeed the case, many of the grammatical features of Middle English, such as the decline of derivational prefixes and the loss of the indefinite man (discussed in McWhorter), might be explained by features of Old Norse, even if the context is not exactly what we would expect for creolization (though some of the features lost in English are found in modern Scandinavian languages). The issue here, as so often in this debate, may be terminological. Since Old English and Old Norse are so closely related, perhaps "koiné" is a more appropriate term for Middle English than "creole". Watts argues that the contact between speakers of English and either Danish or Old Norse in the Danelaw would have created linguistic forms "similar to those resulting from processes of koïneisation in which two mutually intelligible language varieties contribute towards a new variety over a period of roughly three generations of speakers" (2011: 98-99) [emphasis mine]. Although Watts (like Domingue, above) hedges his bets, the argument is quite good. In a general discussion of historical linguistics, Hock and Joseph identify three conditions that must be met for the establishment of a koiné: (1) the languages in question are closely related or even mutually intelligible dialects; (2) the languages are of about equal prestige; and (3) no outside language is available as a link language (1996: 388). All three of these conditions are met in the context of the ninth- and tenth-century English Danelaw. Siegel's definition also emphasizes the significance of mutual intelligibility:

\footnotetext{
A koine is a stabilized contact variety which results from the mixing and subsequent levelling of features of varieties which are similar enough to be mutually intelligible, such as regional or social dialects. This occurs in the context of increased interaction or integration among speakers of these varieties. (2001: 175)
}

Evidence for mutual intelligibility can be found in Townend's (2002) booklength study of Anglo-Norse contact during the Viking Age, in which modern methods are adapted to investigate the historical situation. In addition to providing evidence of mutual intelligibility, Townend also argues that the English and Norse were of roughly equal prestige (the second of Hock and Joseph's criteria for koinezation):

My suspicion is that Norse and English were roughly adstratal in Viking Age England - that is, they enjoyed more less equal prestige. For if Old English were of 
much greater prestige one would expect the rapid death of Old Norse and few Norse loans in Old English; and if Old Norse were of much greater prestige, one would expect many Norse loans in Old English of a non-need nature, and certainly not the death of Old Norse. (1996: 204)

The historical contact setting is therefore much better suited to koinezation than creolization, though of course the two processes share similarities. Siegel (2001) makes a convincing argument that creoles and koinés, while differing significantly from each other in their genesis, structure, and social context, fall at opposite extremes of a shared continuum of language contact varieties.

McWhorter also sees features of koinezation in Anglo-Norse contact. As a comparison, he notes that in the koiné Hindustani of Fiji, grammatical features are often picked "cafeteria style" from the dialects in contact, and that in some cases the simplification of a feature occurs even where all dialects share the same form (2005: 306). This situation is plausible in Viking Age England, he asserts, because complexity in a newly learned language is likely to be lost when there is interference with a related first language:

\begin{abstract}
A non-native speaker of English, confronted with three forms of the article corresponding to gender assignments that often conflicted between Old English and Old Norse, would plausibly have made do with a single gender-neutral marker rather than applying their native genders to their version of English. Koine data worldwide... indicate that when structures are cognate but distinct in closely related varieties, the speaker of one of them is as likely to eliminate their reflex of that feature as to preserve it even when doing the latter would not appreciably impede communication (2005: 308).
\end{abstract}

The accumulated weight of such evidence is enough to make a "koinezation hypothesis" worthy of further consideration to explain the transition from Old to Middle English. ${ }^{2}$

In the above discussion, there is tacit agreement. Advocates and critics of the creolization hypothesis discuss Middle English as descending from Old English (the substrate in the creolization hypothesis), with Old Norse and Norman French having a greater or lesser role in influencing the development of the West Germanic language. However, Emonds and Faarlund (2014) shift the ancestry of English to the North Germanic family, arguing that Middle English descended from the Anglicized Old Norse spoken in the Danelaw, with Old English taking the role of foreign influencer. This claim falls somewhat outside a discussion of the creolization hypothesis, but may be seen as a competing contrarian take on

2 Some of the changes that occurred in the development of Middle English, such as the paradigmatic leveling described here by McWhorter (2005), are parallel to changes in the transition from Classical to Koiné Greek, the original source of the linguistic term. 
the available evidence. Actually, when the authors do mention the hypothesis (mainly in footnotes), it is with something like contempt. Clearly, they see the creolization debate as resulting from scholars being unwilling to consider the possibility of Middle English as a North Germanic language:

\footnotetext{
The oddity of Middle English "borrowing" from Scandinavian has spawned a miniindustry promoting the idea that Middle English is a creole. The maxim for this school of thought seems to be "we must be cautious, as historically, anything can happen. That is, there are no predictive principles of language change, and Middle English proves it." Such reasoning is obviously circular. (2014: 27)
}

Emonds and Faarlund base their conclusions on an examination of a broad range of syntactic evidence (more than 20 constructions), making the reasonable point that lexical evidence is of less value in determining linguistic inheritance (after all, Modern English would be a Romance language if familial membership were determined by counting lexemes). While the argumentation of these authors finds a degree of approval (see, for example, the review by Lightfoot 2016), their syntactic evidence is answered with devastating force by Bech and Walkden (2016), who also point out Emonds and Faarlund's neglect of phonological evidence, and by Stenbrenden (2016), who shows their argumentation to be anachronistic - that is, it uses grammatical features as evidence without attention to when those features are attested. Furthermore, it should be added that some of the evidence against creolization (summarized above), such as late West Saxon case syncretism and the increasing frequency of functors, also serves as evidence against Emonds and Faarlund. These markers are early signs of English's syntactic transition to analytic syntax, strengthening the standard claim that Old English is the ancestor of Middle English. Emonds and Faarlund argue that "the morphological simplification was mediated by language contact, and the simplified inflection cannot in itself be used as an argument for either position" (2014: 150). However, this would only be the case if the simplification were not evident in West Saxon during the late Old English period.

Again, Emonds and Faarlund are not themselves proponents of a creolization hypothesis for Middle English, but their claim of North Germanic ancestry for the language, with its headline grabbing power (at least in Scandinavia), hints at another aspect of what makes the creolization hypothesis so enduring. Issues of language and identity are always salient, but English presents a special case. The language dominates multiple spheres of international communication, and there are more combined L1 and L2 speakers of English than there have been for any language in the history of the world (Crystal 1997). People have strong feelings, both positive and negative, about the language and its empire. But what if the stories that English speakers have told themselves about the English language are not true? What if Vikings (or some other group or groups) spoke the aboriginal 
language rather than the revered Anglo-Saxons associated with Beowulf, Bede, and King Alfred the Great? Such theories challenge not only linguistic dendrograms, but mythologies of linguistic identity that have been passed down for centuries and become deeply embedded in educational curricula and national self-esteem.

\section{Creolization and Universal Grammar}

Even without this high-stakes context, however, it should be clear that identifying an historical language as a creole is a difficult task. This is especially true when we insist on the strict definition that a creole is a nativized pidgin. One must trace a language's history back to a pidgin stage in order to confirm a diachronic relationship that began during a time of language contact. For the case of Middle English, Görlach (1986) argues not only that we have no evidence of a pidgin stage, but that Old English and Old Norse were too similar for pidginization even to have occurred. But how could such a claim be tested empirically? Are there synchronic criteria for identifying which languages are creoles even without observing the creolization process in the historical record?

Markey (1982) identifies a set of such criteria for classifying Afrikaans, but McWhorter notes that there has generally been a reluctance among linguists to think in terms of special creole-specific traits because of concerns that such a list might be ill-construed, as though these traits mark creoles as inferior languages. After all, he points out, linguists often feel compelled to demonstrate that all languages are equal, and a set of distinguishing characteristics that mark creoles as exceptional might make the language appear somehow unequal - an "other" among the world's languages. Milroy (2001b) makes the same point, noting that in many cases our scholarly declarations on these matters may be directed by ideological considerations. In fact, he identifies the exact same a priori belief as McWhorter - namely, that all languages are fundamentally equal - as a certainty which is ardently held despite the fact that it cannot be demonstrated empirically (2001b: 624). This is a conflict that I believe has underlain much of the debate over the creolization hypothesis and the interest it has generated. If English is understood as a creole, then the "othering" of creoles by their linguistic characteristics is perhaps not so problematic. Moreover, even if English is not understood as a creole, the debate sheds light on issues that otherwise might be ignored. The question persists: Can we classify languages into different groups on the basis of criteria such as grammatical complexity without attaching value judgments of superiority and inferiority?

McWhorter himself recalls the cognitive dissonance he experienced when he was asked by a student about whether creoles could be identified outside their historical context. Like most linguists, he assumed as an "article of faith" that 
variable complexity between two languages in particular aspects of their structure should "balance out" once every aspect had been examined. In other words, if a language were found to have little complexity in one area of its grammar (say, nominal inflections), then there should be a higher level of complexity elsewhere, leading to equivalence between all languages in terms of their complete description. This non-empirical assumption seems supported by Chomsky's theory of Universal Grammar (UG), which relies on the claim that all forms of languages are reflections of an underlying linguistic apparatus based in the human genetic code.

\footnotetext{
The concept of UG initiated by Chomsky can be defined as the scientific theory of the genetic component of the language faculty... It is the theory of that feature of the genetically given human cognitive capacity which makes language possible, and at the same time defines a possible human language. UG can be thought of as providing an intensional definition of a possible human language, or more precisely a possible human grammar.... (Roberts 2016: 2)
}

UG has come under increasing criticism over the last decade (e.g., Christiansen \& Chater 2009, Evans \& Levinson 2009, Tomasello 2009, Dąbrowska 2015, among others), but Chomsky's theory has arguably been "the predominant approach in linguistics for almost 50 years" (Dąbrowska 2015: 1). One implication of the theory is that all languages should be governed, at least at some level, by the same grammatical structure. Although this grammar would not necessarily need to be expressed in the same degree of complexity in every language, many linguists have at least had the feeling that it should be so, as exemplified in McWhorter's anecdote (and, I might add, my own experience). Yet McWhorter was troubled by his response to the student, which he later decided had been doctrinaire and unreflective. He returned to the matter and concluded that creoles do share certain structural characteristics with each other that distinguish them from other languages.

The formalization of this discovery is called the Creole Prototype hypothesis. McWhorter was not the first to consider formal criteria for identifying creoles outside of a clear historical context (again, see Markey 1982 for criteria used to classify Afrikaans), but McWhorter's hypothesis is notable for its efficiency. He finds three features that all creoles lack: inflectional morphology, contrastive tone (such as in Chinese, where pitch alone is enough to distinguish lexemes), and noncompositional derivational morphology (as in the English understand). These three features are examples of what a person would often struggle with when learning a language without formal schooling. More generally, McWhorter argues that creoles should exhibit less "overspecification" (unnecessary complexity such as gender and various verbal markers), because this sort of complexity, which is unnecessary for communication, only accrues over 
generations. The point is not to rank languages by complexity, but to identify languages that lack the kind of unnecessary complexity that could not have emerged in the first generations following creolization. Arguably, English exhibits less complexity and overspecification than any other Germanic language, even Afrikaans, a "semi-creole" descendant of Dutch, which is a cousin of English in the West Germanic language family. Nevertheless, by the rather strict definition of the Creole Prototype hypothesis, Middle English would still not be considered a creole, because it exhibits only two of the three required features. This conclusion rather strikingly affirms Domingue's rather tentative take on the creolization hypothesis, which concluded with the claim that Middle English is perhaps best described as "very much alike a creole" (1977: 89).

Despite his own initial state of uneasiness, McWhorter's hypothesis has little in common with creole theories that arose in the nineteenth-century milieu of racism and linguistic ethnocentrism. Differences in complexity notwithstanding, a creole is obviously just as useful for human communication as any other language, and questions of linguistic inferiority are really beside the point. This position has been stated repeatedly by modern linguists - for example, by Poussa, who asserts creoles have full expressive power even if they may be less fully developed in some respects than other languages (1982: 70) - yet some linguists feel that theories such as the Creole Prototype hypothesis represent a throwback to reactionary views of language. DeGraff, for example, is unflinching in his condemnation of any theory that might somehow segregate creoles from other languages, asserting that "the Creole prototype has actually little to contribute to our insights into the definitely-not-so-simple mechanics of universal grammar and no relevance to current debates about the correct analyses of an array of complex Creole structures" (2003: 400). But DeGraff also takes the rather extreme position that pidgins and creoles do not actually exist (which recalls Bailey and Maroldt in their original framing of the creolization hypothesis), and he argues that it is erroneous and prejudicial to view the linguistic processes that form them as exceptional.

\section{Conclusion}

To conclude, it should be noted that creolization, understood as the creative act of a generation of speakers growing up with a pidgin, entails no pejorative judgment. In fact, it would only be possible for language learners to convert a rudimentary communication system such as a pidgin into a full-fledged language in a single generation if their cognitive apparatus was inherently suited to the complex phonological, syntactic, and semantic rules that the creolization process requires. In this view, the fact of creolization is a testament to the astonishing linguistic creativity of creole speakers, and modern creolization theories should 
not be mistaken as having anything in common with the colonialist absurdities of nineteenth-century linguistic theory. Yet it is unsurprising that theories of creolization become particularly controversial when applied to a case like Middle English. More is at stake in such a discussion than might first meet the eye - in our understanding of creole theory, in our political views on English and other standard world languages, and in even in theories of Universal Grammar and the standard inheritance model of historical linguistics. The scholarly question of whether English is a creole is thus of inherent rhetorical interest and worthy of continued discussion, even if the evidence (as reviewed above) is mostly onesided. Sometimes the merit of asking a question is not just in its answer, but in the issues that question encourages us to explore along the way.

\section{REFERENCES}

Allen, Cynthia. 1997. Middle English case loss and the 'creolization' hypothesis. English Language and Linguistics 1.1. 63-89. DOI: 10.1017/S1360674300000368

Bailey, Charles James \& Karl Maroldt. 1977. The French lineage of English. In Jürgen Meisel (ed.), Langues en contact: Pidgins, creoles, Tübingen: TBL. 21-53.

Bech, Kristin \& George Walkden. 2016. English is (still) a West Germanic language. Nordic Journal of Linguistics 39.1. 65-100. DOI: 10.1017/S0332586515000219

Christiansen, Morten H. \& Nick Chater. 2009. The myth of language universals and the myth of universal grammar. Behavioral and Brain Sciences 32.5. 452-453. DOI: 10.1017/S0140525X09990641

Crystal, David. 1997. English as a global language. Cambridge: Cambridge University Press. DOI: 10.1017/CBO9780511486999

Dalton-Puffer, Christiane. 1995. Middle English is a creole and its opposite: On the value of plausible speculation. In Jacek Fisiak (ed.), Linguistic change under contact conditions, Berlin: Mouton de Gruyter. 35-50. DOI: 10.1515/9783110885170.35

Danchev, Andrei. 1997. The Middle English creolization hypothesis revisited. In Jacek Fisiak, (ed.), Studies in Middle English linguistics, Berlin: Mouton de Gruyter. 79-108. DOI: 10.1515/9783110814194.79

DeGraff, Michel. 2003. Against creole exceptionalism. Language 79.2. 391-410.

Domingue, N. Z. 1977. Middle English: Another creole? Journal of Creole Studies 1. 89-100.

Dąbrowska, Ewa. 2015. What exactly is Universal Grammar, and has anyone seen it? Frontiers in Psychology 6:852. 1-17. DOI: 10.3389/fpsyg.2015.00852

Emonds, Joseph E. \& Jan Terje Faarlund. 2014. English: The language of the Vikings. Olomouc: Palacký University Press.

Evans, Nicholas \& Stephen C. Levinson. 2009. The myth of language universals: Language diversity and its importance for cognitive science. Behavioral and Brain Sciences 32.5. 429-448. DOI: 10.1017/S0140525X0999094X

Görlach, Manfred. 1986. Middle English - a creole? In Dieter Kastovsky \& Aleksander Szwedek (eds.), Linguistics across historical and geographical boundaries, Berlin: Mouton de Gruyter. 329-344. 
Hartman, Megan E. 2016. New applications for word-foot theory. In M. J. Toswell \& Lindy Brady (eds.), Early English poetic culture and meter: The influence of G. R. Russom, Kalamazoo: Medieval Institute Publications. 73-92.

Hock, Hans Henrich \& Brian D. Joseph. 1996. Language history, language change, and language relationship: An introduction to historical and comparative linguistics. Berlin: Walter de Gruyter \& Co.

Hogg, Richard M. 1997. Some remarks on case marking in Old English. Transactions of the Philological Society 95.1. 95-109. DOI: 10.1111/1467-968X.00014

Ingham, Richard. 2014. The maintenance of French in later medieval England. Neuphilologische Mitteilungen, 115.4. 425-448.

Lightfoot, David W. 2016. Review of Joseph E. Emonds \& Jan Terje Faarlund, English: The language of the Vikings, 2014. In Language 92.2. 474-477.

Markey, Thomas L. 1982. Afrikaans: Creole or non-creole? Zeitschrift für Dialektologie und Linguistik, 49.2. 169-207.

McWhorter, John H. 2005. Defining creole. Oxford: Oxford University Press.

McWhorter, John H. 2008. Our magnificent bastard tongue: The untold history of English. New York. NY: Gotham Books.

Milroy, James. 2001a. Language ideologies and the consequences of standardization. Journal of Sociolinguistics 5.4. 530-555. DOI: 10.1111/1467-9481.00163

Milroy, James. 2001b. Response to Sally Johnson: Misunderstanding language? Journal of Sociolinguistics 5(4). 620-625. DOI: 10.1111/1467-9481.00170

O'Neil, David. 2017. A syntactic basis for the distribution of metrical types in Beowulf. The Mediaeval Journal 7.1.29-59. DOI: 10.1484/J.TMJ.5.115346

O’Neil, David. 2018. English as the lingua franca of international publishing. World Englishes 37.2. 146-165. DOI: 10.1111/weng. 12293

O'Neil, David. 2020, forthcoming. Syntax, prosody, and the Brut: Metrical continuity in the early English alliterative tradition. Enarratio 23.

Plag, Ingo. 1998. Review of Christiane Dalton-Puffer, The French influence on Middle English morphology: A corpus-based study of derivation, 1996. In Language 74.2. 392-395.

Phillipson, Robert. 1992. Linguistic imperialism. Oxford: Oxford University Press.

Poussa, Patricia. 1982. The evolution of early standard English: The creolization hypothesis. Studia Anglia Posnaniensia 14. 69-85.

Roberts, Ian. 2016. Introduction. In Ian Roberts (ed.), The Oxford handbook of Universal Grammar. Oxford: Oxford University Press. DOI: 10.1093/oxfordhb/9780199573776.013.1

Russom, Geoffrey R. 2017. The evolution of verse structure in Old and Middle English poetry: From the earliest alliterative poems to iambic pentameter. Cambridge: Cambridge University Press. DOI: 10.1017/9781316562925

Siegel, Jeff. 2001. Koine formation and creole genesis. In Norval Smith \& Tonjes Veenstra (eds.), Creolization and contact, Amsterdam: Benjamins.175-197. DOI: 10.1075/cll.23.08sie

Stenbrenden, Gjertrud F. 2016. Why English is not dead: A rejoinder to Emonds and Faarlund. Folia Linguistica Historica 37.1. 239-279. DOI: 10.1515/flih-2016-0008

Tomasello, Michael. 2009. Universal grammar is dead. Behavioral and Brain Sciences 32.5. 470 71. DOI: $10.1017 / \mathrm{S} 0140525 \mathrm{X} 09990744$

Thomason, Sarah Grey \& Terrence Kaufman. 1988. Language contact, creolization, and genetic linguistics. Berkeley, CA: University of California Press.

Townend, Matthew. 2002. Language and history in Viking Age England: Linguistic relations between speakers of Old Norse and Old English. Turnhout: Brepols. 
Trotter, David M. 2017. Middle English creolization. In Laurel J. Brinton \& Alexander Bergs (eds.), Middle English, Berlin: Mouton de Gruyter. 224-238. DOI: 10.1515/9783110525328012

Watts, Richard J. 2011. Language myths and the history of English. Oxford: Oxford University Press. DOI: 10.1093/acprof:oso/9780195327601.001.0001 